\title{
Archaeoentomological indicators of long-term food plant storage at the Prehispanic granary of La Fortaleza (Gran Canaria, Spain)
}

\author{
Pedro Henríquez-Valido ${ }^{\text {a, }}$, Jacob Morales ${ }^{\text {a }}$, Paloma Vidal-Matutano ${ }^{\text {a }}$, Marco Moreno-Benítez ${ }^{\text {b }}$, \\ Ángel Marchante-Ortega ${ }^{a}$, Amelia Rodríguez-Rodríguez ${ }^{\mathrm{a}}$, Jean-Bernard Huchet ${ }^{\mathrm{c}, \mathrm{d}, \mathrm{e}}$ \\ ${ }^{\text {a }}$ G. I. Tarha. Dpto. Ciencias Históricas, Universidad de Las Palmas de Gran Canaria, C/ Pérez del Toro 1, Las Palmas de Gran Canaria, Spain \\ b Tibicena Arqueología y Patrimonio, Las Palmas de Gran Canaria, Spain \\ ${ }^{c}$ UMR 5199 - PACEA, Anthropologie des Populations Passées et présentes, Université de Bordeaux, 33615, Pessac Cedex, France \\ ${ }^{\mathrm{d}}$ UMR 7209 - Archéozoologie, Archéobotanique: sociétés, pratiques et environnements, Muséum National d'Histoire Naturelle, case postale 56, 55 rue Buffon, 75005, \\ Paris, France \\ ${ }^{\mathrm{e}}$ Institut de Systématique, Evolution et Biodiversité, ISYEB, UMR 7205 CNRS MNHN UPMC EPHE, Muséum national d'Histoire naturelle, CP 50 (Entomologie), Paris \\ Cedex, 05, France
}

\section{A R T I C L E I N F O}

\section{Keywords:}

Canary islands

Prehispanic period

Cave granaries

Plant remains

Food

Insects

Pests

\begin{abstract}
A B S T R A T
Storage is crucial to the sequence of food management. It is nonetheless at times difficult to recognize in the archaeological record due to problems of preservation of ancient food remains. Archaeoentomology in this sense can be of great value as it sheds light on past storage techniques. This study presents the findings of the archaeoentomological analyses carried out at the ancient granary of La Fortaleza (Gran Canaria, Spain, ca. 600$1450 \mathrm{AD}$ ), a site where the favorable conditions of preservation allow recording the food plants and insect pests associated with storage. Moreover, the recovery of several taxa of primary and secondary pests connected to different stages of store infestation (i.e. Sitophilus granarius (L.), Oryzaephilus surinamensis (L.), Tenebrioides mauritanicus (L.), Mezium americanum (Laporte de Castelnau), Stegobium paniceum (L.) and Cryptolestes sp.) offers data as to the storage conditions and time intervals of the Prehispanic Canarian indigenous population. Finally, new radiocarbon-datings of the pests yield data casting light on the origin and spread of several cosmopolitan taxa such as M. americanum and on past relations between Africa, Europe and the New World.
\end{abstract}

\section{Introduction}

There are numerous cultural contexts marked by specific nutritional and ecological conditions in which the study of insects merges with that of archaeology. Within the bioarchaeological disciplines, the study of insect remains from Quaternary deposits is a science that emerged in Britain in the second half of the 20th century (Coope, 1977, 1986; 1990; Osborne, 1969; Buckland, 1976). Designated as "Quaternary entomology", this discipline includes two distinct entities respectively referred as "Palaeoentomology" and "Archaeoentomology". Although based on the same principles and methods, the first focuses on examining insect assemblages for palaeoclimatic and palaeoenvironmental reconstructions, while the second, exclusively related to archaeological contexts, serves to reconstruct the way of life and health of past populations, the evolution of dietary patterns, agro-pastoral practices, and the impact of human activities on the past environments.
The advent of the Neolithic period, with the emergence of sedentarization, animal husbandry, agriculture and population growth, had an impact on local natural ecosystems that inevitably had a significant influence on biodiversity and, consequently, on invertebrate fauna. The study of the insect and parasites recovered from archaeological contexts reveals that many managed to adapt perfectly to these new, anthropogenic niches and, consequently, had a considerable impact on the subsistence economy, as they provoked major losses of food reserves.

Archaeoentomology yields data leading to the reconstruction of human-made environments or indoor spaces and the activities that took place in these areas, as the presence of certain pests in archaeological contexts can be linked to specific plants and animal species (Buckland, 1979; Forbes and Milek, 2014; Giordani et al., 2020). The discipline also serves to identify features such as pens and latrines (Panagiotakopulu and Van Der Veen, 1997; Panagiotakopulu et al., 2010). Furthermore, insects can be a factor in the degradation of organic matter and hence

\footnotetext{
* Corresponding author.

E-mail address: pedro.henriquez102@alu.ulpgc.es (P. Henríquez-Valido).
} 
their study can serve as a taphonomic marker of the conditions of preservation of certain sites (Adams, 1984). Another interesting application relates to past storage since many species of insects are closely linked to types of food and their different stages of processing (Buckland, 1990; Panagiotakopulu, 2001; Huchet, 2017).

Despite the great potential of entomological analyses to identify storage spaces, there is still little archaeoentomological research focusing on granaries and other specific structures due to problems of preservation and identification of these foods and features. This study offers evidence of archaeobotanical and archaeoentomological remains from the granary of La Fortaleza (Gran Canaria), a collective place of storage serving between the 6 th- 15 th centuries $\mathrm{AD}$. The organic materials recovered at this site include both plant remains and insect pests in an exceptional state of preservation. Their study identifies which pests are associated with the different types of stored food, determines the conditions in which the granary was maintained, estimates the time of silage, and finally offers unpublished data as to the function of Gran Canaria's collective granaries and subsistence strategies.

\section{Storage and collective granaries in Gran Canaria}

The Canary Islands is an archipelago in the eastern Atlantic comprising eight volcanic islands that are at least $100 \mathrm{~km}$ from the North African coast (Fig. 1). They were initially settled since at least the outset of the 1st millennium AD by Berber populations from the Northwest of Africa (Springer, 2001; Maca Meyer et al., 2004; Hagenblad et al., 2017; Rodríguez-Varela et al., 2017; Fregel et al., 2019, Velasco-Vázquez et al., 2020). Although they initially settled all the islands, the different populations remained isolated from each other leading each island to individual historical developments until the arrival of European explorers in the 14th century AD. To cover their nutritional needs, the first settlers brought from the continent cereals, pulses and a single fruit (fig), as well as livestock (sheep/goats and pigs). The development of livestock and agriculture on the different islands progressed unevenly, with that of Gran Canaria predominating over that of the other islands as evidenced both by the archaeological record (Morales, 2010) and by diet analyses of human remains of Prehispanic populations (Velasco Vázquez, 1998; Delgado-Darias, 2009; Arnay de la Rosa et al., 2009, 2010) (see Fig. 2).

The many large indigenous settlements on the Island of Gran Canaria suggests a substantial population characterized by a complex society (Onrubia Pintado, 2003). Both archaeological evidence and information gleaned from old texts penned by early European explorers signal that agriculture played a fundamental role in the diet of the indigenous population (Morales, 2010). Among the most compelling archaeological features linked to agriculture are the collective fortified granaries distributed throughout the island. These sites share links with the igudar troglodytic features and the magasins de falaise of the Maghreb (Marcy, 1940; Onrubia Pintado, 1986, 2003; Rodríguez et al., 2011-2012). These structures in Gran Canaria were dug into volcanic rock cliffs of difficult access near fertile agricultural soils (Morales et al., 2018). Their inner spaces consist of silos directly cut into the rock organized in rows or along the walls of circular chambers. Although the silos no longer retain their original covers, they were once sealed by large stones or wood doors (Morales et al., 2014; Naranjo-Mayor and Rodríguez-Rodríguez, 2015). Two factors explain the conditions of desiccation inside the silos that led to the preservation of foodstuffs for centuries. The first is the constant temperature and humidity throughout the year averting the spread of pests (Culver and Pipan, 2009; Bescherer and Beaudry, 2015). The second is their inaccessibility, despite that they remained open, which reduced postdepositional disruption by humans, large mammals and other external factors.

Radiocarbon datings of the plants and insects from several granaries indicate that they served mainly between the 10th and 15th centuries $\mathrm{AD}$ (Morales et al., 2018). This time frame coincides with a period of great demographic growth among the indigenous population as evidenced by the expansion of settlements and cemeteries (Morales et al.,
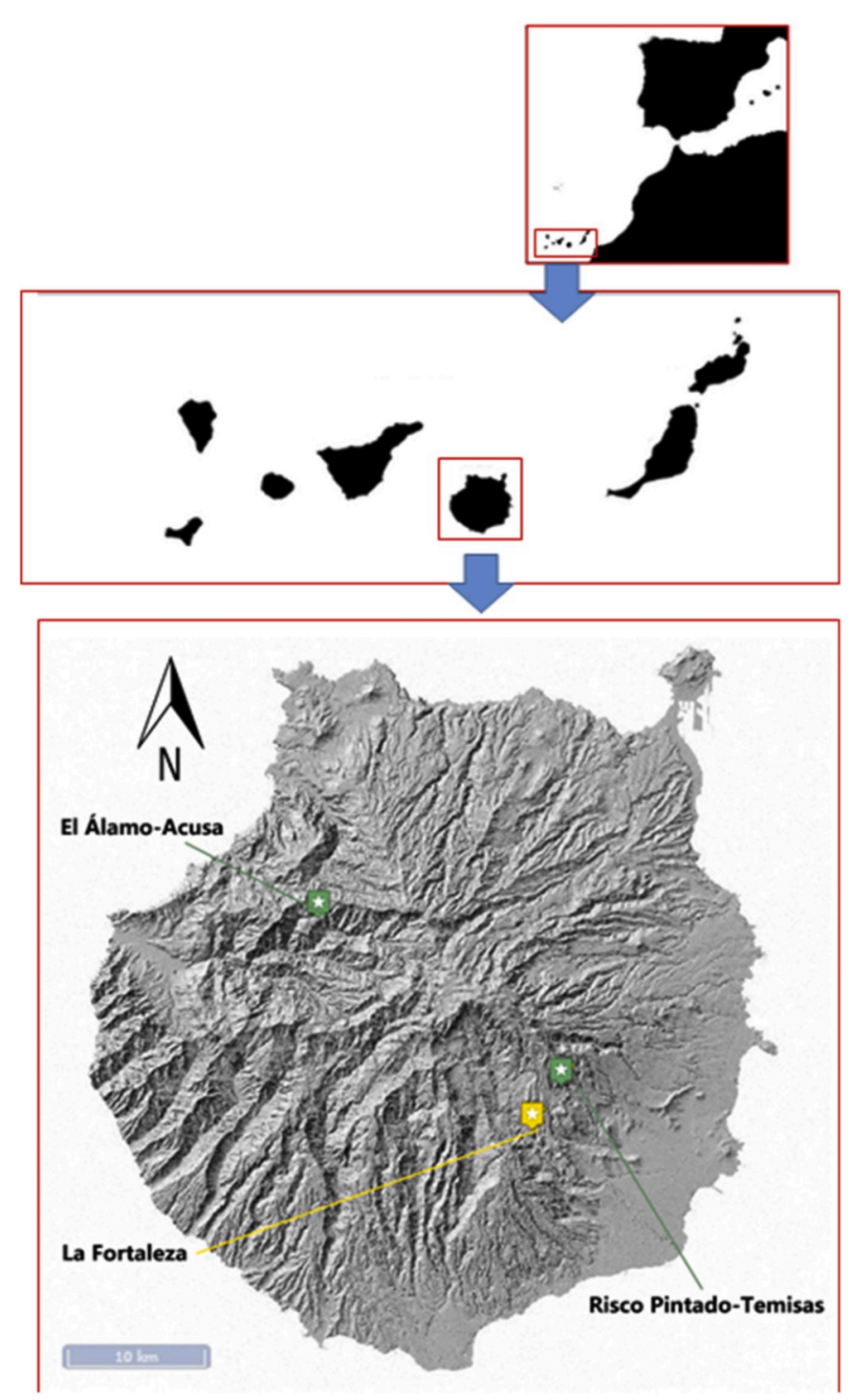

Fig. 1. Top: map of the Canary Islands. Center: Position of Gran Canaria in the archipelago. Bottom: Digital shadow model of Gran Canaria with the sites mentioned in the text (source: IDECanarias.es).

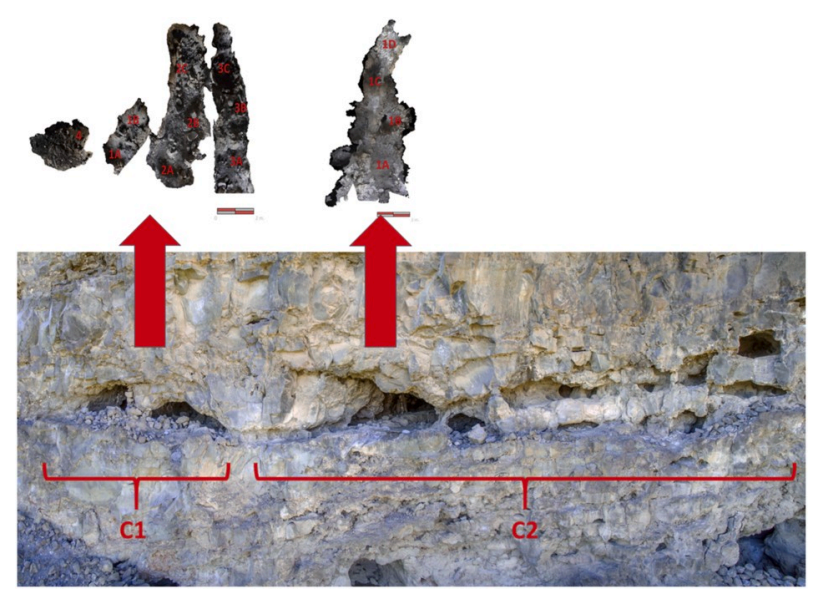

Fig. 2. La Fortaleza (Cave 31). Top: Floor of the silos of Unit 1 and of Silo 1 of Unit 2. Unit 1 is marked as C1 and Unit 2 as C2. Bottom: view of the mouths of the caves along the cliff. 
2014; Alberto Barroso et al., 2019).

The study of the storage features evidences that the products intended for storage most likely comprised both cultivated and wild plants (Morales et al., 2014, 2018; Henríquez-Valido et al., 2019). The domestic species were barley (Hordeum vulgare subsp. vulgare), durum wheat (Triticum durum), lentil (Lens culinaris), broad bean (Vicia faba) and fig (Ficus carica). Barley and figs are among the main crops of the early Canarian diet (Morales, 2010). Seeds of wild species such as Canarian palm (Phoenix canariensis) and Canary Island pine (Pinus canariensis) suggest that they could have also been stored. Finally, certain silos contained laurel leaves (Laurus novocanariensis), a plant known for its insecticide properties (Morales et al., 2018) and active principles that inhibit the spread of insects and fungi (Rodilla et al., 2008).

The data available to date suggest that the storage techniques were complex and designed to preserve the crops for long periods of time (Morales et al., 2018). Besides introducing plants serving as insecticides, the indigenous Canarians developed other strategies such as storage of grains attached to their ear or in their pod. This technique offers protection from temperature fluctuations and pests, but also requires larger silos.

The volume of the harvest increases when the grains are stored with their glumes and other floral covers forming part of their spike. Although storage in these spaces supposes a greater seed aeration, improving their conservation, it also implies a greater investment in labor to fashion the storage unit (Sigaut, 1988). Several of the silos reveal traces of mortar or plaster covers, as well as channels cut through the rock to increase air circulation. Despite the efforts to condition and maintain the silos, the samples reveal the presence of pests through damaged grains and insects themselves, in particular granary weevils (Sitophilus granarius L.) (Morales et al., 2014, 2018; Henríquez-Valido et al., 2019).

Unprocessed plants were likewise stored in these granaries. Finds of hand driven querns at the granary of Cenobio de Valeron, a site dated by radiocarbon between 1040 and $1440 \mathrm{cal} \mathrm{AD}$, suggests food processing took place at the granary itself (Naranjo-Mayor and Rodríguez-Rodríguez, 2015). Moreover, the absence of unprocessed plants in settlements also bolsters the notion that the querns in these granaries served to process the cereal after storage, before its transport to where it was consumed (Morales et al., 2018).

\section{La Fortaleza granary}

La Fortaleza (510 m a.s.1.) is in the Municipality of Santa Lucía de Tirajana in the southeast of Gran Canaria. It is in the bed of the Caldera de Tirajana, a large erosive depression that includes three knife-shaped elevations named respectively La Fortaleza Grande, La Fortaleza Chica and Titana (Moreno, 2017). These natural towers rise above a basaltic base and are covered by ignimbritic flows of rhyolitic to trachyphonolitic and peralkaline (Balcells et al., 1990).

The vegetation surrounding the site is typical of the thermocanarian bioclimatic level of the semiarid ombroclimate with forests of Canary Island pine (Pinus canariensis) in the higher altitudes and Canary Island palm (Phoenix canariensis) in the mid-low areas accompanied by other thermophilic shrubs. It is noteworthy that some of these shrubs such as balo (Plocama pendula) are also recorded among the anthracological finds of the granary (Vidal-Matutano et al., 2020).

The indigenous populations dug out and raised dwellings, places of worship, cemeteries, as well as granaries, in these volcanic towers between the 5th and 15th centuries AD. The dating of an ovicaprine bone from a structure at the top of La Fortaleza Grande offers a range between the 5th-7th centuries AD (Moreno et al., 2017), although historical records suggest that the settlement was occupied until the end of the 15th century (Moreno et al., 2017).

The granary is actually located at a great height with access requiring climbing equipment. Although the site is made up of a series of caves cut into the eastern slope of La Fortaleza Grande, its main features correspond to two groups of caves (Cave 31) interconnected by a horizontal passage $6.1 \mathrm{~m}$ long.

\section{Material and methods}

Samples were collected from all of the silos of Cave 31 of the granary of La Fortaleza. These hollows contain fillings only a few centimeters thick and thus do not offer conventional archaeological stratigraphic sequences. The fills in the silos consist of a combination of aeolian deposits, elements detached from their walls and an organic matrix of plant and insect remains (Fig. 3). These factors, together with the difficulty of access, led to the decision to only collect several random samples from each silo. In the case of the smaller silos, samples were limited to a single 1-L probe collected from the middle. The probes from the larger silos of Unit 1, and Silo 1 of Unit 2, by contrast, were collected from several equidistant points (a, b, c and d). A total of $18 \mathrm{~L}$ of sediment was collected. Despite this relatively modest volume, the samples are rich in organic materials and yield enough data to undertake the comparative study.

The samples were then dry-screened with meshes of 10, 5, 2, 1 and $0.5 \mathrm{~mm}$. The finds surpassing $2 \mathrm{~mm}$, analyzed in their entirety, were separated according to their nature (wood, seeds and insects). Those recovered in the 1 and $0.5 \mathrm{~mm}$ meshes, due their abundance, were subsampled through a riffle box. Their study focused respectively on $1 / 4$ and $1 / 8$ of their volume. Several samples verified with meshes inferior to $0.5 \mathrm{~mm}$ ( 250 and $125 \mu \mathrm{m}$ ) revealed no insect or botanical remains.

The intention of sub-sampling was to reduce the work time (each probe can contain more than 1000 plant and insect remains) and to estimate the number of invertebrates in each silo. This was carried out by multiplying the number of specimens identified in each probe by four in the case of the $1 \mathrm{~mm}$ sieve and by eight in the case of the $0.5 \mathrm{~mm}$ sieve. This method, applied in earlier studies of Gran Canaria granaries (Morales et al., 2014; Henríquez-Valido et al., 2019) and other sites elsewhere containing desiccated organic remains (Alonso Martínez et al., 2000; Panagiotakopulu et al., 2010, 2013), has proven the most suitable. The number of pronota, the exoskeleton's most durable part, served to calculate the minimum number of insects (MNI) of each taxon. If other parts of the insects were more numerous, then that number was applied for the calculation.

Separating the plant and entomological remains was carried out with a Nikon SMZ-2T (8-80 X) stereo microscope. Identification of insect remains was undertaken by consulting specialized publications (Haines, 1991; Delobel and Tran, 1993) and by directly comparing the specimens from the modern reference collection in the Archaeology Laboratory of the Department of Historical Sciences of the University of Las Palmas de Gran Canaria and the PACEA Laboratory of the University of Bordeaux.

Digital images of the insect remains were carried out at the PACEA

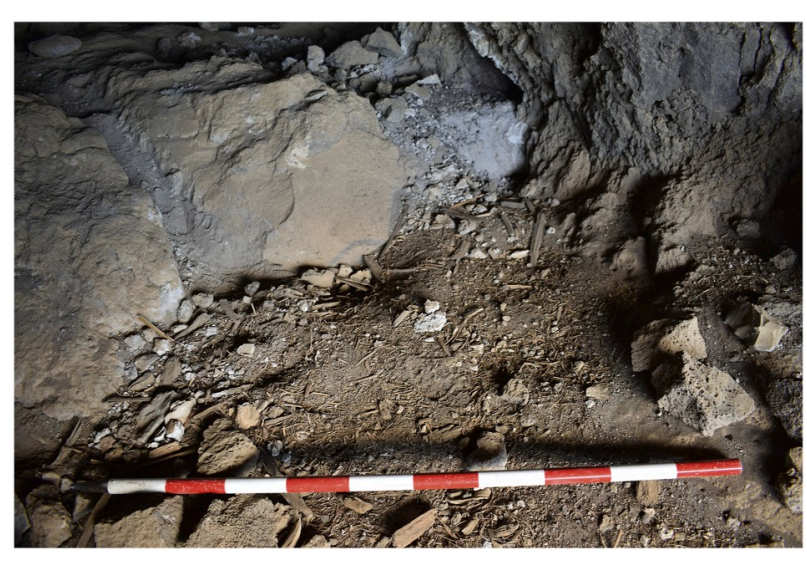

Fig. 3. View of Silo 3a (Unit 1) serving as an example of how the storage features are preserved at the granary of La Fortaleza. 
Laboratory with a Canon E0S 6D digital camera (zoom MP-E $65 \mathrm{~mm}$ ) mounted on a Kaiser RTx column. The zstepper was controlled through the focus stacking software Helicon Remote 3.8.6w and images were processed using Helicon focus 6 . The digital images were ultimately imported into Adobe Photoshop CS4 for post-processing, labelling and plate composition.

\subsection{Radiocarbon datings}

Ten AMS datings were obtained on the materials from the silos (Table 1). Four were carried out on insects [S. granarius, Oryzaephilus surinamensis (L.), Stegobium paniceum (L.), and Mezium americanum (Laporte de Castelnau)] providing radiocarbon dates that range between 776 and $981 \mathrm{cal} \mathrm{AD}$ and 1184-1275 cal AD. The other six datings were carried out on plant remains from the silos containing insects so as to confirm their antiquity. They range from 545 to $645 \mathrm{cal} \mathrm{AD}$ and 1274-1393 cal AD.

These datings as a whole indicate that the granary of La Fortaleza served for at least 800 years, between the 6th and 14th centuries AD. However, most of the radiocarbon dates point to the 1169-1393 cal AD range, suggesting this time period witnessed the most intensive use of the silos.

\section{Results and discussion}

\subsection{Archaeobotanical remains}

The dating of the content of the silos suggest the storage of plants by the Prehispanic populations analogous to that observed at other granaries in Gran Canaria (Table 2). Although the analyses of the current study are still in progress, its preliminary findings indicate the predominance of barley (H. vulgare) and fig (F. carica) (ca. 90\%) and lesser proportions of durum wheat ( $T$. durum) and pulses, i.e., lentils (L. culinaris) and broad beans ( $V . f a b a)$.

There is likewise evidence that certain wild species were collected and stored, notably Canary Island palm dates (Phoenix canariensis), pine nuts (Pinus canariensis) and bay leaves (L. novocanariensis). Mocán (V. mocanera), a small fruit tree endemic to the Canary Islands and Madeira, is also present.

Wood remains are also recorded at La Fortaleza (Table 3). Among them are a few anthracological (wood charcoal) remains probably associated with the disintegration of the mortar covering the walls since mortar usually contained ashes and charcoals. Most, in turn, are xylological (desiccated) fragments corresponding to different uses (e.g. tools, containers, elements serving for the spatial organization inside the silos, silo covers, etc) (Vidal-Matutano et al., 2020). Other fragments, especially those of Canary Island pine (Pinus canariensis), could have served as constructive features. To a lesser extent, and spread out heterogeneously in the silos, are the remains of fig tree ( $F$. carica), dragon tree (Dracaena sp.), palm tree (Phoenix canariensis), balo ( $P$. pendula), Asteraceae and woody legumes (Fabaceae). There is also evidence of different monocotyledons probably evidencing plant fibers serving to make ropes, mats or containers. A few fragments of Lauraceae in certain silos can also be linked either to the introduction of green laurel branches with their leaves as insecticide (Morales et al., 2018; Vidal-Matutano et al., 2020) or for woodworking.

\subsection{Archaeoentomological remains}

The statistical estimation of the insects of the granary of La Fortaleza indicates 9143 subfossil insect remains belonging to 2 classes, 4 orders, 14 families and 22 genera (Table 4; Fig. 4 and Supplementary data S1). Coleoptera at $98.83 \%$ is the most represented order. The other classes are Isopoda $(0.62 \%)$, Hymenoptera $(0.50 \%)$ and Heteroptera $(0.05 \%)$. Arachnida are represented by the remains of spiders and mites.

Archaeoentomological analyses of the granary of La Fortaleza identified at least six species of pests that inflict damage to stored plants. The most common is the granary weevil (S. granarius) represented by 4291 remains ( $47 \%$ of the entomological assemblage). This worldwide species is one of the main dangers to stores of barley and wheat (Delobel and Tran, 1993) and thrives in temperate climatic zones in environments of approximately $30^{\circ} \mathrm{C}$ and $70 \%$ relative humidity (Haines, 1991).

This species is highly synanthropic as it depends on humans for mobility. This is due, unlike the two other Sitophilus species (Sitophilus oryzae (L.) and Sitophilus zeamais Mots.), to the loss of its ability to fly (Huchet, 2017). It is the main pest at La Fortaleza as it bored holes into the whole grains to lay its eggs (Buckland, 1990; Trematerra et al., 2000; Panagiotakopulu and Buckland, 2018). Its origin is probably in the Middle East (Zohary, 1969) from where it spread throughout Europe during the Neolithic (Plarre, 2010). Archeologically it has been detected in different Neolithic contexts of Greece and Turkey (Panagiotakopulu and Buckland, 2018), as well as in the Bronze Age stores of Akrotiri (Santorini, Greece) (Panagiotakopulu and Buckland, 1991). In Egypt it was found among the remains of barley deposited as offerings in the tomb of the pyramid of Saqqara (Solomon, 1965; Panagiotakopulu, 2001). This pest in France is also known in Romanized contexts at Amiens in a granary that burned down at the end of the 2nd century BC (Matterne et al., 1998) as well as at the Gallo-Roman villa of Touffréville (Calvados, France) where it led to the identification of storage spaces (Ponel et al., 2000). This pest in Great Britain is among the charred cereal deposit at Malton, Yorkshire (Buckland, 1981) and in the cereal deposits of Tanner Row, York (Kenward and Carrott, 2006). In America it is identified in colonial Boston at the 17th century site of Cross Street Back Lot (USA) associated with products stored in a household (Bain, 1998). It is nonetheless very likely that this pest attained the Americas earlier, with the first European settlers. In Gran Canaria, the granary weevil is identified at the granary of El Álamo-Acusa between 1020 and 1150 cal AD (Morales et al., 2014) and at Risco Pintado-Temisas between 1020 and 1155 cal AD (Henríquez-Valido et al., 2019).

La Fortaleza offers nonetheless the oldest range of dates (776-981 cal AD) of $S$. granarius in Gran Canaria. This timeframe, together with that obtained of the Gran Canaria granaries of El Álamo-Acusa (Morales et al., 2014) and Risco Pintado-Temisas (Henríquez-Valido et al., 2019), confirms its contemporaneity with the indigenous Prehispanic

Table 1

Radiocarbon dates of the insect and seed remains from the granary of La Fortaleza.

\begin{tabular}{|c|c|c|c|c|c|c|c|}
\hline Material & Common designation & Type material & Lab. Code & Sample ref. & Location & 14C age BP & cal. $\mathrm{AD}(95,4 \%)$ \\
\hline Visnea mocanera & mocán & seed & Beta-477343 & FOR17S5C2VIS & Silo 5-Unit 2 & $1470 \pm 30$ & $545-645$ \\
\hline Sitophilus granarius & granary weevil & insect & Beta-477349 & FOR17S2AC1SIT & Silo 2a-Unit 1 & $1140 \pm 30$ & $776-981$ \\
\hline Lens culinaris & lentil & seed & Beta-477347 & FOR17S2C2LENS & Silo 2- Unit 2 & $950 \pm 30$ & $1024-1155$ \\
\hline Mezium americanum & black spider beetle & insect & Beta-477351 & FOR17S1DC2MEZ & Silo 1d- Unit 2 & $810 \pm 30$ & $1169-1270$ \\
\hline Stegobium paniceum & biscuit beetle & insect & Beta-554542 & FOR17C2S1DSTE & Silo 1-Unit 2 & $800 \pm 30$ & $1184-1275$ \\
\hline Oryzaephilus surinamensis & sawtoothed grain beetle & insect & Beta-477350 & FOR17S1AC2ORY & Silo 1a- Unit 2 & $760 \pm 30$ & $1219-1284$ \\
\hline Pistacia lentiscus & mastic tree & seed & Beta-477348 & FOR17S1AC1PIS & Silo 1a- Unit 1 & $680 \pm 30$ & $1270-1390$ \\
\hline Hordeum vulgare & barley & seed & Beta-477344 & FOR17S2AC1HOR & Silo 2a-Unit 1 & $670 \pm 30$ & $1274-1391$ \\
\hline Hordeum vulgare & barley & seed & Beta-477346 & FOR17S2BC1HOR & Silo $2 b$ - Unit 1 & $670 \pm 30$ & $1274-1391$ \\
\hline Hordeum vulgare & barley & seed & Beta-477345 & FOR17S2CC1HOR & Silo $2 \mathrm{c}$-Unit 1 & $660 \pm 30$ & $1276-1393$ \\
\hline
\end{tabular}


Table 2

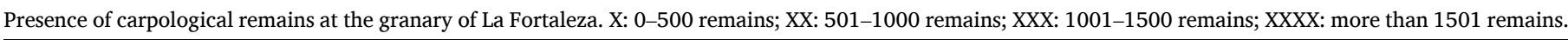

\begin{tabular}{|c|c|c|c|c|c|c|c|c|c|c|c|c|c|c|c|c|c|c|c|}
\hline & & \multicolumn{9}{|c|}{ Unit 1} & \multicolumn{9}{|c|}{ Unit 2} \\
\hline & & 1a & $1 b$ & $2 a$ & $2 \mathrm{~b}$ & $2 c$ & $3 a$ & $3 b$ & $3 c$ & 4 & $1 \mathrm{a}$ & $1 \mathrm{~b}$ & 1c & $1 d$ & 2 & 3 & 4 & 5 & 6 \\
\hline Cultivated plant & $\begin{array}{l}\text { Common } \\
\text { name }\end{array}$ & & & & & & & & & & & & & & & & & & \\
\hline Hordeum vulgare, grain & Barley & $\mathrm{x}$ & $\mathrm{x}$ & $\mathrm{x}$ & $\mathrm{x}$ & $\mathrm{x}$ & $\mathrm{x}$ & & & $\mathrm{x}$ & & & $\mathrm{x}$ & $\mathrm{x}$ & $\mathrm{x}$ & & $\mathrm{x}$ & $\mathrm{x}$ & $\mathrm{x}$ \\
\hline $\begin{array}{l}\text { Hordeum vulgare, articulated } \\
\text { set of hulls }\end{array}$ & Barley & $\mathrm{x}$ & $\mathrm{x}$ & $\mathrm{x}$ & $\mathrm{x}$ & $\mathrm{x}$ & $\mathrm{x}$ & $\mathrm{x}$ & $\mathrm{x}$ & $\mathrm{x}$ & $\mathrm{x}$ & $\mathrm{x}$ & $\mathrm{x}$ & $\mathrm{x}$ & $\mathrm{x}$ & $\mathrm{x}$ & $\mathrm{x}$ & $\mathrm{x}$ & $\mathrm{x}$ \\
\hline Hordeum vulgare, rachis & Barley & $\mathrm{x}$ & $\mathrm{xxx}$ & $\mathrm{xx}$ & $\mathrm{xx}$ & $\mathrm{x}$ & $\mathrm{x}$ & $\mathrm{x}$ & $\mathrm{x}$ & $\mathrm{x}$ & $\mathrm{x}$ & $\mathrm{x}$ & $\mathrm{x}$ & $\mathrm{x}$ & $\mathrm{x}$ & $\mathrm{xx}$ & $\mathrm{xxx}$ & $\mathrm{x}$ & $\mathrm{x}$ \\
\hline Hordeum vulgare, basal rachis & Barley & $\mathrm{x}$ & $\mathrm{x}$ & $\mathrm{x}$ & $\mathrm{x}$ & $\mathrm{x}$ & $\mathrm{x}$ & & & $\mathrm{x}$ & $\mathrm{x}$ & $\mathrm{x}$ & $\mathrm{x}$ & $\mathrm{x}$ & $\mathrm{x}$ & $\mathrm{x}$ & $\mathrm{x}$ & & \\
\hline Triticum durum, grain & Wheat & & & & $\mathrm{x}$ & & $\mathrm{x}$ & & & & $\mathrm{x}$ & & & $\mathrm{x}$ & & & & $\mathrm{x}$ & \\
\hline Triticum durum, rachis & Wheat & $\mathrm{x}$ & $\mathrm{x}$ & $\mathrm{x}$ & $\mathrm{x}$ & $\mathrm{x}$ & $\mathrm{x}$ & $\mathrm{x}$ & $\mathrm{x}$ & $\mathrm{x}$ & $\mathrm{x}$ & & & & $\mathrm{x}$ & $\mathrm{x}$ & $\mathrm{x}$ & $\mathrm{x}$ & \\
\hline Triticum durum, basal rachis & Wheat & & $\mathrm{x}$ & $\mathrm{x}$ & $\mathrm{x}$ & $\mathrm{x}$ & & $\mathrm{x}$ & & $\mathrm{x}$ & & & & & $\mathrm{x}$ & & & & \\
\hline Vicia faba, hilum & Broad bean & $\mathrm{x}$ & $\mathrm{x}$ & & $\mathrm{x}$ & $\mathrm{x}$ & $\mathrm{x}$ & $\mathrm{x}$ & $\mathrm{x}$ & $\mathrm{x}$ & $\mathrm{x}$ & & & $\mathrm{x}$ & $\mathrm{x}$ & $\mathrm{x}$ & & $\mathrm{x}$ & \\
\hline Vicia faba, pod & Broad bean & & & & & & & & $\mathrm{x}$ & & & & & & & & & & \\
\hline Vicia sativa, seed & Broad bean & & & & & & & & & & & & & & & $\mathrm{x}$ & & & \\
\hline Lens culinaris, seed & Lentil & $\mathrm{x}$ & & & & & & $\mathrm{x}$ & & $\mathrm{x}$ & & & $\mathrm{x}$ & & $\mathrm{x}$ & $\mathrm{x}$ & $\mathrm{x}$ & $\mathrm{x}$ & $\mathrm{x}$ \\
\hline Lens culinaris, hilum & Lentil & & & $\mathrm{x}$ & $\mathrm{x}$ & $\mathrm{xx}$ & $\mathrm{x}$ & $\mathrm{x}$ & & $\mathrm{x}$ & $\mathrm{x}$ & $\mathrm{x}$ & $\mathrm{x}$ & & $\mathrm{x}$ & & $\mathrm{x}$ & $\mathrm{x}$ & \\
\hline Lens culinaris, pod & Lentil & & & & & & & & & $\mathrm{x}$ & $\mathrm{x}$ & $\mathrm{x}$ & $\mathrm{xx}$ & & $\mathrm{x}$ & & $\mathrm{x}$ & $\mathrm{x}$ & \\
\hline Ficus carica, endocarp & Fig tree & $\mathrm{xxx}$ & $\mathrm{x}$ & $\mathrm{xxx}$ & $\mathrm{xxx}$ & $\mathrm{x}$ & $\operatorname{xxxx}$ & $\mathrm{x}$ & $\mathrm{xx}$ & $\mathrm{xxxx}$ & $\mathrm{xx}$ & $\mathrm{x}$ & $\mathrm{x}$ & $\mathrm{x}$ & $\mathrm{xxx}$ & $\mathrm{xxxx}$ & $\mathrm{xxx}$ & $\mathrm{xx}$ & $\mathrm{xxxx}$ \\
\hline Ficus carica, peduncle & Fig tree & $\mathrm{x}$ & $\mathrm{x}$ & $\mathrm{x}$ & $\mathrm{x}$ & & $\mathrm{x}$ & $\mathrm{x}$ & & $\mathrm{x}$ & $\mathrm{x}$ & & $\mathrm{x}$ & & $\mathrm{x}$ & & $\mathrm{x}$ & & $\mathrm{x}$ \\
\hline Ficus carica, fruit & Fig tree & & & & & & $\mathrm{x}$ & & $\mathrm{x}$ & $\mathrm{x}$ & & $\mathrm{x}$ & & & & & $\mathrm{x}$ & & \\
\hline \multicolumn{20}{|l|}{ Harvested wild plants } \\
\hline $\begin{array}{l}\text { Laurus novocanariensis, leaf } \\
\text { fragment }\end{array}$ & Laurel & $\mathrm{x}$ & $\mathrm{x}$ & $\mathrm{x}$ & $\mathrm{x}$ & $\mathrm{x}$ & $\mathrm{x}$ & $\mathrm{x}$ & $\mathrm{x}$ & $\mathrm{x}$ & $\mathrm{x}$ & $\mathrm{x}$ & $\mathrm{x}$ & $\mathrm{x}$ & $\mathrm{x}$ & & & $\mathrm{x}$ & $\mathrm{x}$ \\
\hline Phoenix canariensis, perianth & $\begin{array}{l}\text { Canarian palm } \\
\text { tree }\end{array}$ & & & & & & $\mathrm{x}$ & & & & & & & & & & & & \\
\hline Phoenix canariensis, rachis & $\begin{array}{l}\text { Canarian palm } \\
\text { tree }\end{array}$ & $\mathrm{x}$ & & & & & $\mathrm{x}$ & & & & & & & & $\mathrm{x}$ & & & & \\
\hline Pinus canariensis, needle & $\begin{array}{l}\text { Canary Island } \\
\text { pine }\end{array}$ & & & $\mathrm{x}$ & & & $\mathrm{x}$ & & & $\mathrm{x}$ & & & $\mathrm{x}$ & & & & & & \\
\hline Pinus canariensis, seed & $\begin{array}{l}\text { Canary Island } \\
\text { pine }\end{array}$ & & & $\mathrm{x}$ & & & $\mathrm{x}$ & & & $\mathrm{x}$ & & & & & & & & $\mathrm{x}$ & \\
\hline Pinus canariensis, cortex & $\begin{array}{l}\text { Canary Island } \\
\text { pine }\end{array}$ & & & $\mathrm{x}$ & & & & & & & & & & & & & & & \\
\hline Pinus canariensis, peduncle & $\begin{array}{l}\text { Canary Island } \\
\text { pine }\end{array}$ & & & & & $\mathrm{x}$ & & & & & & & & & & & & & \\
\hline Pistacia lentiscus, seed & Mastic tree & $\mathrm{x}$ & & & & & & & & $\mathrm{x}$ & $\mathrm{x}$ & & & & $\mathrm{x}$ & & & $\mathrm{x}$ & \\
\hline Visnea mocanera, seed & Mocán & & & & & & & & & & & & & & & & & $\mathrm{x}$ & \\
\hline
\end{tabular}

population. As noted above, the granary weevil is synanthropic and requires humans to disperse. It is therefore reasonable to speculate that it was introduced in Gran Canaria together with the grains transported to the island by the first settlers from the northwest of Africa.

It must be noted, however, that the datings obtained from barley from the same silo containing the granary weevil suggest a later date (1270-1393 cal AD). This insect certainly appears in the granary with the stored seeds. There is also no doubt as to the consistency of the AMS dating of the remains of the insect preserved by desiccation in another archaeological context (Panagiotakopulu et al., 2015). Hence the dates linked to this pest preceding those of the grains can be explained by the lack of systematic cleaning of the silos allowing certain pests to remain.

The granary weevil, as previously stated, likewise spread to other granaries in Gran Canaria such as El Álamo-Acusa and Risco PintadoTemisas (Morales et al., 2014; Henríquez-Valido et al., 2019). This dispersion throughout different parts of the island, coupled with a mobility depending on humans, suggests an exchange of contaminated seeds.

Another insect infesting the granaries of La Fortaleza is the sawtoothed grain beetle (O. surinamensis), a cosmopolitan pest that thrives in granaries in tropical climates. It is a secondary synanthropic pest since it is not identified among the grains collected before the harvest and is unable to attack whole grains. Hence it requires grains to be damaged by a primary pest or processed by humans. It rarely flies, and most often develops in spaces at $20-35{ }^{\circ} \mathrm{C}$ and $70 \%$ r.h. (Haines, 1991 ; Halstead, 1993). Its adults usually consume the larvae of other pests such as S. granarius (Lepesme, 1944; Huchet, 2017).

The sawtoothed grain beetle very likely has an origin in Africa (Panagiotakopulu and Buckland, 2018), although the oldest evidence of this pest so far is from a Neolithic context in Macedonia where a head was recovered in sediments from the earliest layers of the site of Mandalo (Valamoti and Buckland, 1995). It is identified in the Bronze Age together with $S$. granarius in the stores of Akrotiri (Santorini, Greece) (Panagiotakopulu and Buckland, 1991). In Egypt, it was contained in one of the jars of Tutankhamun's tomb (Zacher, 1937). In Roman times, O. surinamensis appears in storage contexts in England (Coope and Osborne, 1968; Buckland, 1981; Kenward and Carrott, 2006), Germany (Buckland, 1981) and Italy (Dal Monte, 1956; Buckland, 1981).

Radiocarbon analyses at La Fortaleza place it in the Prehispanic period between 1219 and $1284 \mathrm{cal} \mathrm{AD}$ and at Risco Pintado-Temisas, also in Gran Canaria, between 886 and 1013 cal AD (Henríquez-Valido et al., 2019). It is therefore safe to assume that the indigenous population had to contend with this pest. Like $S$. granarius, it is synanthropic and was probably introduced with seeds from the continent. This suggests that it was already widespread in the Maghreb, the origin of the archipelago's first inhabitants.

Another pest of interest at La Fortaleza granary is the American spider beetle ( $M$. americanum). Although there is little data regarding its biology, it is a cosmopolitan Ptinidae that consumes the residues of food and other insects. It is classified for this reason as a secondary pest (Haines, 1991). It consumes dried animal and plant remains such as skins, fruits and seeds, and develops in temperate zones (Hagstrum and Subramanyam, 2009).

There is no archaeological evidence of this pest in Europe prior to 1492. The find at the site of Chimù-Chancay (Peru) is the only case in the Americas in Pre-Inca funerary context (McCauley et al., 2014; Huchet, 2017). Certain authors, nonetheless, claim that the origin of M. americanum is in the African continent (Borowski, 2009), or possibly, although not corroborated, in the Canary Islands (Borowski, 2017). The problems in tracking its origin may in fact stem in part from its poor 


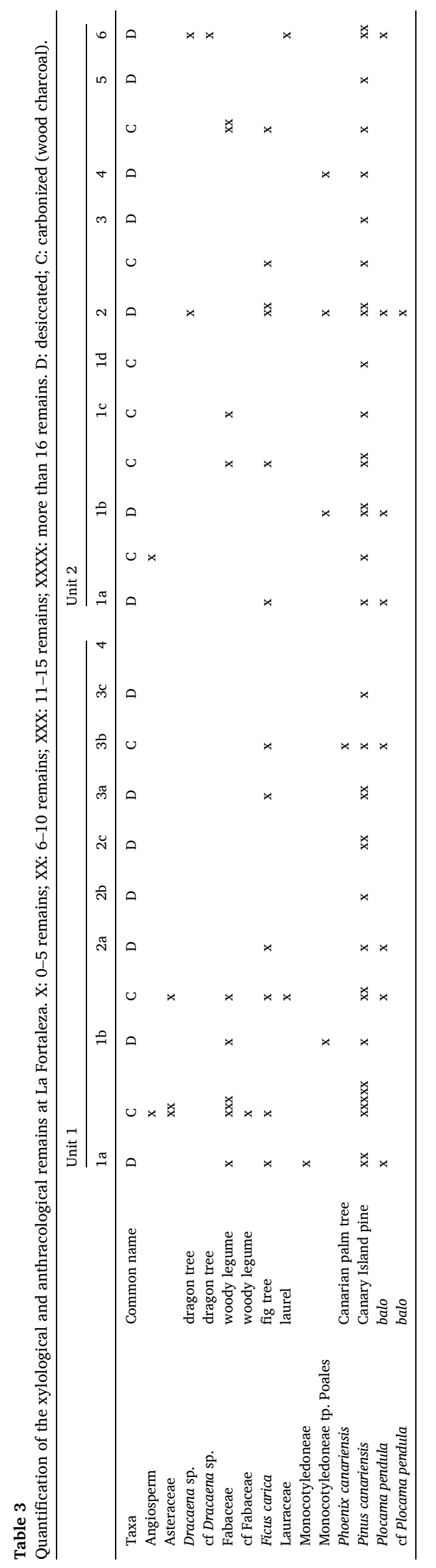

conservation in archaeological contexts due to its weak sclerotized exosqueleton. M. americanum was, nonetheless, identified elsewhere in the Canary Islands at the granary of Risco Pintado-Temisas (Henríquez-Valido et al., 2019). Radiocarbon datings of it at La Fortaleza indicate a 1169-1270 cal $\mathrm{AD}$ range confirming a precocious presence (preceding the 15th century) in the Canary Islands. In any case, the question of this taxon's origin requires further research.

The biscuit beetle ( $S$. paniceum) is a secondary pest that affects processed products. Its presence at La Fortaleza is the first to be dated in Gran Canaria, and confirms that it was likewise introduced by the early indigenous Canarians (1184-1275 cal AD). It is recorded beyond the archipelago since the Bronze Age in Greece (Panagiotakopulu and Buckland, 1991) and the Iron Age in the United Kingdom (Chowne et al., 1986). It was identified in ancient Egypt in the tomb of Tutankhamun (Alfieri, 1931) and in a variety of other storage features (Levinson and Levinson, 1985, 1994; Panagiotakopulu, 2001). It is also known in England in Roman times (Buckland, 1981). This beetle develops in environments between 15 and $34{ }^{\circ} \mathrm{C}$ and from 60 to $90 \%$ r.h. Under optimal conditions it can live up to 40 days (Haines, 1991).

Other less numerous pests at La Fortaleza are not directly dated and therefore cannot be assumed to have been contemporary to the Prehispanic Canarians. The most common is the cadelle beetle Tenebroides mauritanicus (L.). Among the members of the family Trogossitidae, this is the only taxon that affects stored products. It is cosmopolitan and not only inflicted damage on stored products but preyed on the other pests cited above (Haines, 1991). Although it probably comes from Africa (Denux and Zagatti, 2010; Huchet, 2017), certain authors claim an origin in the forests of southern Europe (Crowson, 1958). Remains of T. mauritanicus are found in Neolithic contexts in Germany (Schmidt, 1998, 2013; Panagiotakopulu and Buckland, 2018). In Egypt it was identified in a cave by the Red Sea storing plant products arriving at the Port of Mersa/Wadi Gawasis (Borojevic et al., 2010). It is also in England among the remains of a Bronze Age shipwreck (Buckland, 1981). It is recorded in Roman Israel among the storage facilities of Masada (Kislev and Simchoni, 2007). It presumably spread across the European continent in Roman times (Huchet, 2017). Although lacking direct AMS dating, the cases at La Fortaleza make up the earliest archaeological evidence of this species in the Canary Islands suggesting that it also arrived with the early settlers from northwestern Africa.

The insect family Tenebrionidae is represented at La Fortaleza by five cases of depressed flour beetle (Palorus cf. subdepressus), a minor pest that consumes both processed plant products (Haines, 1991) and those consumed previously by primary pests such as $S$. granarius which is also its prey. It is identified in Egypt in the storage rooms of Amarna together with S. granarius (Panagiotakopulu, 2001) and in Roman contexts in England (Buckland, 1981). Its presence at La Fortaleza is, once again, the earliest evidence of this species in a Canarian archaeological context. Although it does not benefit from any direct radiocarbon dating confirming its Prehispanic context, its association with stored food and other synanthropic insects suggests it was introduced, like other cases, by the first settlers from North Africa.

Cryptolestes sp. (Laemophloeidae), also present at La Fortaleza, is a secondary granary pest that consumes flour and materials attacked previously by primary pests such as $S$. granarius. Several species of this family are known to damage plant products (Hagstrum and Subramanyam, 2009). However, only Cryptolestes minutus (or C. pusillus) (Olivier), Cryptolestes ater (Olivier) and Cryptolestes granulatus (Wollaston) are recorded in Gran Canaria (Machado and Oromí, 2000). Members of this genus are cited in Roman contexts in England (C. ferrugineus: Buckland, 1981; Kenward and Carrott, 2006).

The diet of the insects identified at La Fortaleza indicates that the silos served to store plant products, for the most part cereals. However, a single Dermestes frischii Kugenlann, an insect known to consume bones, cheese and dried fish and other insects (Hagstrum and Subramanyam, 2009), was recorded in Silo 6 - Unit 2. This pest could also have arrived accidently at the granary as it consumed other non-stored foods 
Table 4

Statistical estimation of insect remains from Units 1 and 2 of the granary of La Fortaleza.

\begin{tabular}{|c|c|c|c|c|c|c|c|c|c|c|c|c|c|c|c|c|c|c|c|c|}
\hline & \multirow[t]{2}{*}{ Common name } & \multicolumn{9}{|c|}{ Unit 1} & \multicolumn{9}{|c|}{ Unit 2} & \multirow[t]{2}{*}{ TOTAL } \\
\hline & & $1 \mathrm{a}$ & $1 \mathrm{~b}$ & $2 \mathrm{a}$ & $2 b$ & $2 c$ & $3 a$ & $3 b$ & $3 c$ & 4 & $1 \mathrm{a}$ & $1 \mathrm{~b}$ & $1 \mathrm{c}$ & $1 d$ & 2 & 3 & 4 & 5 & 6 & \\
\hline \multicolumn{21}{|l|}{ Pests } \\
\hline \multicolumn{21}{|l|}{ Coleoptera } \\
\hline $\begin{array}{l}\text { Sitophilus granarius, } \\
\text { entire }\end{array}$ & Granary weevil & 4 & 4 & 28 & 4 & & 69 & 24 & 24 & 8 & 16 & & 20 & 32 & 40 & 55 & 18 & 12 & & 358 \\
\hline $\begin{array}{l}\text { Sitophilus granarius, } \\
\text { head }\end{array}$ & Granary weevil & & 8 & 428 & 40 & 24 & 476 & 20 & 32 & & & 36 & 4 & & 144 & 24 & 8 & 16 & 16 & 1.276 \\
\hline $\begin{array}{l}\text { Sitophilus granarius, } \\
\text { pronotum }\end{array}$ & Granary weevil & & 8 & 560 & 36 & 24 & 452 & 24 & 40 & & 32 & 40 & 8 & 24 & 216 & 80 & 24 & 61 & 8 & 1.637 \\
\hline $\begin{array}{l}\text { Sitophilus granarius, } \\
\text { abdomen }\end{array}$ & Granary weevil & 12 & & 152 & 24 & & 224 & & 36 & 8 & 28 & 4 & 8 & 24 & 48 & 44 & 24 & 20 & & 656 \\
\hline $\begin{array}{l}\text { Sitophilus granarius, } \\
\text { elytra }\end{array}$ & Granary weevil & & & 104 & 24 & & 160 & & & & 16 & & & & 40 & 16 & & & & 360 \\
\hline $\begin{array}{l}\text { Oryzaephilus } \\
\text { surinamensis, entire }\end{array}$ & $\begin{array}{l}\text { Sawtoothed } \\
\text { grain beetle }\end{array}$ & & & 72 & & & & 8 & & & 25 & & & 8 & 12 & 40 & 8 & & & 173 \\
\hline $\begin{array}{l}\text { Oryzaephilus } \\
\text { surinamensis, head }\end{array}$ & $\begin{array}{l}\text { Sawtoothed } \\
\text { grain beetle }\end{array}$ & & & & & & 8 & 16 & 4 & & 72 & 8 & & & & 2 & 8 & & 32 & 150 \\
\hline $\begin{array}{l}\text { Oryzaephilus } \\
\text { surinamensis, } \\
\text { pronotum }\end{array}$ & $\begin{array}{l}\text { Sawtoothed } \\
\text { grain beetle }\end{array}$ & 8 & & & 48 & 32 & 40 & 64 & 60 & & 336 & 40 & & & 133 & 8 & 24 & & 96 & 889 \\
\hline $\begin{array}{l}\text { Oryzaephilus } \\
\text { surinamensis, } \\
\text { abdomen }\end{array}$ & $\begin{array}{l}\text { Sawtoothed } \\
\text { grain beetle }\end{array}$ & & & & & & 64 & 40 & 12 & & 180 & 96 & 24 & & 64 & 13 & 28 & & 8 & 529 \\
\hline cf. Casapus, head & & & & & & & & & & & & & & & & 1 & & & & 1 \\
\hline $\begin{array}{l}\text { cf. Casapus, } \\
\text { pronotum }\end{array}$ & & & & & & & & & & & & & & & & 2 & & 4 & & 6 \\
\hline cf. Casapus, elytra & & 4 & & 2 & & & & & & & & & & & 10 & 8 & 2 & 2 & 2 & 30 \\
\hline $\begin{array}{l}\text { Mezium americanum, } \\
\text { entire }\end{array}$ & $\begin{array}{l}\text { Black spider } \\
\text { beetle }\end{array}$ & 17 & 1 & & 12 & 1 & & & 4 & 24 & 16 & 148 & 82 & 113 & 209 & 116 & 91 & 33 & 80 & 947 \\
\hline $\begin{array}{l}\text { Mezium americanum, } \\
\text { pronotum }\end{array}$ & $\begin{array}{l}\text { Black spider } \\
\text { beetle }\end{array}$ & & & & 32 & & & 40 & & & & & 8 & & 40 & 16 & & 12 & 16 & 164 \\
\hline $\begin{array}{l}\text { Mezium americanum, } \\
\text { abdomen }\end{array}$ & $\begin{array}{l}\text { Black spider } \\
\text { beetle }\end{array}$ & & & & 4 & & & & & & & & & & & & & & & 4 \\
\hline $\begin{array}{l}\text { Stegobium paniceum, } \\
\text { entire }\end{array}$ & Biscuit beetle & 8 & & & & & 3 & & 4 & & 8 & & 228 & 348 & 68 & & & 5 & & 672 \\
\hline $\begin{array}{l}\text { Stegobium paniceum, } \\
\text { tórax }\end{array}$ & Biscuit beetle & & & & & & 1 & & & & & & 64 & & & & & & & 65 \\
\hline $\begin{array}{l}\text { Stegobium paniceum, } \\
\text { abdomen }\end{array}$ & Biscuit beetle & & & & & & 8 & & & & & & 40 & & 8 & & & 12 & & 68 \\
\hline $\begin{array}{l}\text { Tenebroides } \\
\quad \text { mauritanicus, entire }\end{array}$ & Cadelle & & & & & & & & & & & & 1 & 1 & & & & & & 2 \\
\hline $\begin{array}{l}\text { Tenebroides } \\
\quad \text { mauritanicus, head }\end{array}$ & Cadelle & & & 12 & 4 & & 16 & 9 & 4 & & & & & & 36 & & 8 & & & 89 \\
\hline $\begin{array}{l}\text { Tenebroides } \\
\text { mauritanicus, } \\
\text { pronotum }\end{array}$ & Cadelle & & & 8 & & 1 & 12 & 1 & 4 & & 8 & & 4 & & 51 & 4 & & & & 93 \\
\hline $\begin{array}{l}\text { Tenebroides } \\
\quad \text { mauritanicus, } \\
\text { abdomen }\end{array}$ & Cadelle & & & & & & & & & & & & & & & & & & & \\
\hline $\begin{array}{l}\text { Tenebroides } \\
\text { mauritanicus, } \\
\text { mandible }\end{array}$ & Cadelle & 8 & & & & & & & & & & & & & & & & & & 8 \\
\hline $\begin{array}{l}\text { Tenebroides } \\
\text { mauritanicus, elytra }\end{array}$ & Cadelle & & & & 4 & & 22 & 4 & 12 & 1 & & & & & 9 & 1 & & & & 53 \\
\hline $\begin{array}{l}\text { Tenebroides } \\
\text { mauritanicus, } \\
\text { pupae }\end{array}$ & Cadelle & & & 4 & & & & & & & & & & & & & & & & 4 \\
\hline Cryptolestes sp. entire & & & & & & & & & & & & & & 4 & & & & & & 4 \\
\hline Cryptolestes sp., head & & & & & & & & & & & 8 & & & & & & & & & 8 \\
\hline $\begin{array}{l}\text { Cryptolestes sp., } \\
\text { pronotum }\end{array}$ & & & & & & & & & & & 8 & & & & & & & & & 8 \\
\hline \multicolumn{21}{|l|}{ No pests } \\
\hline \multicolumn{21}{|l|}{ Coleoptera } \\
\hline Hegeter sp., head & & & & & & 2 & & & & 2 & & & 1 & & 1 & 1 & & & 1 & 8 \\
\hline Hegeter sp., pronotum & & 1 & & & & & & 1 & & 2 & & & 1 & & 2 & 1 & 6 & 1 & 2 & 17 \\
\hline Hegeter sp., elytra & & & & & & 2 & 1 & & & & & & & & 8 & 2 & 12 & & & 25 \\
\hline Hegeter sp., sternum & & & & & & & & & 4 & & & & & & 9 & & 2 & & & 15 \\
\hline $\begin{array}{l}\text { Hegeter sp., } \\
\text { metasternum }\end{array}$ & & & & & & & & & & & & & & & & & 1 & & & 1 \\
\hline \multicolumn{21}{|l|}{$\begin{array}{l}\text { Melansis cf. kazsabi, } \\
\text { head }\end{array}$} \\
\hline \multirow{2}{*}{$\begin{array}{l}\text { Melansis cf. kazsabi, } \\
\text { pronotum }\end{array}$} & & & & & & & & & & & & & & & & & 1 & & 1 & 2 \\
\hline & & & & & & & & & & & & & & & & & & & 1 & 1 \\
\hline
\end{tabular}


Table 4 (continued)

\begin{tabular}{|c|c|c|c|c|c|c|c|c|c|c|c|c|c|c|c|c|c|c|c|c|}
\hline & \multirow[t]{2}{*}{ Common name } & \multicolumn{9}{|c|}{ Unit 1} & \multicolumn{9}{|c|}{ Unit 2} & \multirow[t]{2}{*}{ TOTAL } \\
\hline & & $1 \mathrm{a}$ & $1 \mathrm{~b}$ & $2 \mathrm{a}$ & $2 \mathrm{~b}$ & $2 c$ & $3 a$ & $3 b$ & $3 c$ & 4 & $1 \mathrm{a}$ & $1 \mathrm{~b}$ & $1 \mathrm{c}$ & $1 d$ & 2 & 3 & 4 & 5 & 6 & \\
\hline \multicolumn{21}{|l|}{$\begin{array}{l}\text { Melansis cf. kazsabi, } \\
\text { abdomen }\end{array}$} \\
\hline $\begin{array}{l}\text { Palorus } \text { cf. } \\
\text { subdepressus, head }\end{array}$ & & & & & & & 8 & & & & & & & & & & & & & 8 \\
\hline $\begin{array}{l}\text { Palorus } \mathrm{cf} \text {. } \\
\text { subdepressus, } \\
\text { pronotum }\end{array}$ & & & & 8 & & & 8 & & & & & & & & 8 & & & & & 24 \\
\hline $\begin{array}{l}\text { Scleron cf. asperulum, } \\
\text { pronotum }\end{array}$ & & & & & & & & & & & & & & 1 & & & & & & 1 \\
\hline $\begin{array}{l}\text { Aphodius } \\
\text { hydrochaeris, } \\
\text { pronotum }\end{array}$ & & & & & & & & & & & & & & & & & 2 & & & 2 \\
\hline $\begin{array}{l}\text { Aphodius } \\
\text { hydrochaeris, head }\end{array}$ & & & & & & & & & & & & & & & & & 1 & & & 1 \\
\hline $\begin{array}{l}\text { Tropinota squalida } \\
\text { canariensis, head }\end{array}$ & & & & & & & & & & & & & & & & & 1 & & 1 & 2 \\
\hline $\begin{array}{l}\text { Tropinota squalida } \\
\text { canariensis, } \\
\text { pronotum }\end{array}$ & & & & & & & & & & & & & & & & & 2 & & & 2 \\
\hline $\begin{array}{l}\text { Tropinota squalida } \\
\text { canariensis, elytra }\end{array}$ & & & & & 1 & & & & & & & & & & & & & 4 & & 5 \\
\hline $\begin{array}{l}\text { Dermestes frischii, } \\
\text { entire }\end{array}$ & & & & & & & & & & & & & & & & & & & 1 & 1 \\
\hline Dermestidae & & & & & & & & & & & 8 & & 16 & 56 & & & & & & 80 \\
\hline $\begin{array}{l}\text { Dermestidae, } \\
\text { pronotum }\end{array}$ & & & & & & & & 1 & & & & & & & & & & & 1 & 2 \\
\hline Dermestidae, pupae & & & & & & & & & & & & & & 4 & & & & & & 4 \\
\hline Latriidae & & & & & & & & & & & & & 1 & & & & & & & 1 \\
\hline Latriidae, pronotum & & & & 8 & & & & 12 & 4 & & & & & & & & & & 8 & 32 \\
\hline \multicolumn{21}{|l|}{ Curculionidae, head } \\
\hline $\begin{array}{l}\text { Curculionidae, } \\
\text { pronotum }\end{array}$ & & & & 8 & & & 8 & & & 4 & 16 & & & & & 8 & & & & 44 \\
\hline \multicolumn{21}{|l|}{ Curculionidae, elytra } \\
\hline \multicolumn{21}{|l|}{ Hymenoptera } \\
\hline Formicidae, head & & & & 8 & & & 8 & & & 4 & & 16 & & & & 8 & & & & 44 \\
\hline \multicolumn{21}{|l|}{ Isopoda } \\
\hline Isopoda, segments & & & & & & & & & & & & 4 & 16 & & 9 & 10 & & & 14 & 53 \\
\hline \multicolumn{21}{|l|}{ Heteroptera } \\
\hline $\begin{array}{c}\text { Heteroptera, } \\
\text { pronotum }\end{array}$ & & & & & & & & & & & 4 & & & & & & & & & 4 \\
\hline \multicolumn{21}{|l|}{ Arachnida } \\
\hline $\begin{array}{l}\text { Arachnida, } \\
\text { chelicerae }\end{array}$ & & & & & & & & & & 5 & & & & & & & 1 & & & 6 \\
\hline Acari & & & & & & 1 & & & & & & & & & & & 1 & & & 2 \\
\hline $\begin{array}{l}\text { Other undetermined } \\
\text { remains }\end{array}$ & & 35 & 27 & 20 & 28 & 39 & 17 & 52 & 4 & 10 & 46 & 44 & 2 & 50 & 1 & 6 & 76 & 38 & 7 & 502 \\
\hline TOTAL & & & & & & & & & & & & & & & & & & & & 9.143 \\
\hline
\end{tabular}

(Kingsolver, 1991). It is therefore possible that it only colonized the silo after its abandonment, perhaps attracted by the modest decaying remains of Soricidae or Muridae, Lacertidae and Columbidae.

Aphodius remains were likewise identified in Silo 4 (Unit 2). Their presence in the granary of this coprophagous family (Beynon et al., 2012) is interpreted either as accidental or due to the use of excrement to prepare the mortar covering the silo's walls.

Finally, the existence of certain insect remains in the silos, not necessarily pests, may be fortuitous. Although members of the genus Scleron, for example, can be present in storerooms (Hagstrum and Subramanyam, 2009), this is not the case of $S$. asperolum, the taxa identified in La Fortaleza.

The origin of the other non-pest insects of the granary of La Fortaleza must be accidental. Their low number also points to an anecdotal nature, probably arriving after the abandonment of the site. There are also insects at the site endemic to the Canary Islands with no relationship to humans such as Hegeter sp., Melansis cf. kazsabi, and Tropinota squalida canariensis Lindberg.

Although primary pests induce the greatest amount of damage due to their consumption of whole grains, secondary pests must be taken into account when assessing the state of stored products (Huchet, 2017) as a granary infested by these pests also suffers total damage that offers compelling information as to the storage timeframe. For this reason, although the percentage of primary pests $(47 \%)$ at La Fortaleza is significantly higher than that of secondary pests (37\%), the latter yields broader information as to the conditions and length of storage.

An example is that the life cycle of $S$. granarius can endure up to one year (Haines, 1991), while that of secondary insects (e.g. O. surinamensis) can extend up to three years and three months in optimal conditions of temperature and humidity (Back and Cotton, 1926; Sahito et al., 2017). Furthermore, the life cycle of T. mauritanicus exceeds a year during which it can lay several eggs (Cotton, 1924).

The life cycles exceeding one year indicate either inadequate conditions of hygiene leading to the infestation or that of grain storage over long stretches of time. As mentioned above, plant processing by the indigenous Prehispanic population could also serve as evidence of longterm storage in these silos. The different techniques linked to preserving grains observed at the sites of Gran Canaria such as storing in their spikes or resorting to insecticide plants bolsters the idea of their desire for long-term crop preservation. Pulse pods and palm rachis also form 

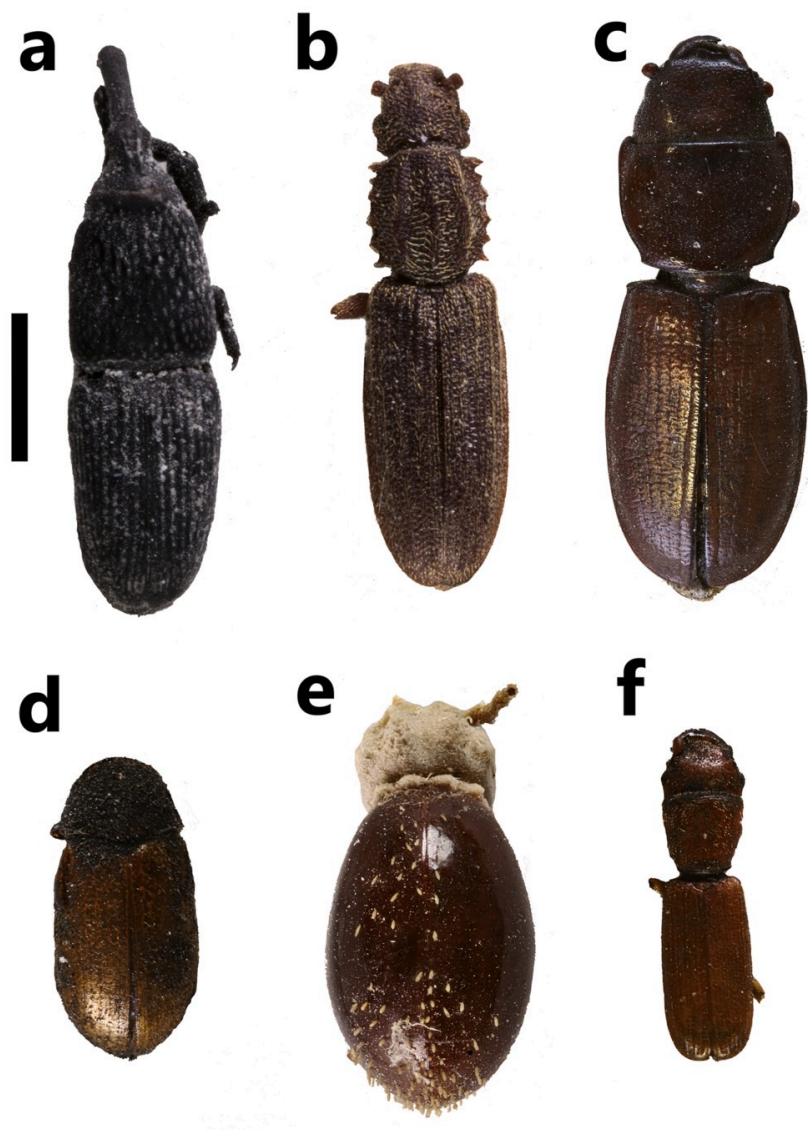

Fig. 4. Views of insect pests from the granary of La Fortaleza: a. granary weevil (Sitophilus granarius); b. saw-toothed grain beetle (Oryzaephilus surinamensis); c. cadelle (Tenebroides mauritanicus); d. biscuit beetle (Stegobium paniceum); e. black spider beetle (Mezium americanum); f. Cryptolestes sp. (scale bar $=1 \mathrm{~mm}$ ).

part of the plants found in the granaries. Hence, cereals, as well as pulses and fruits, were stored in their natural envelopes (Morales et al., 2018). Resorting to these techniques, although not totally effective against certain insects, suggests that the ancient Canarians were aware of the pests.

Complete pest elimination (with the exception of those that can survive in extreme temperatures, e.g. below $10{ }^{\circ} \mathrm{C}$ or above $50{ }^{\circ} \mathrm{C}$ ) requires very long periods of time in subtropical climates such as that of Gran Canaria (Bell, 2014) because the warm weather allows survival of eggs and insects not detected by the naked eye. It is probable that a lack of silo care and short intervals between each use, essential for total insect eradication, led to a propagation of secondary pests over a long period of time. Radiocarbon dates from S. granarius of Silo 2a-Unit 1 are ca. 300 years earlier than barley from the same silo (Table 1), confirming an incomplete cleaning of the silos. Although cooling below $10^{\circ} \mathrm{C}$ for a prolonged period of time is difficult to achieve in subtropical climates such as that of the Canary Islands, heating above $50{ }^{\circ} \mathrm{C}$ was probably effective. Yet there is currently no evidence implying the use of fire for pest eradication.

Long-term food storage also requires frequent ventilation, especially when the seeds are stored in their ears (Sigaut, 1988). This leads to a drop in temperature inside the silo preventing the arrival of secondary pests. The proliferation of pests, on the other hand, increases silo temperature and humidity provoking more damage (Trematerra et al., 2000). The presence of both primary and secondary pests in the granary of La Fortaleza therefore indicates either a lack of silo aeration or that the grains were not sufficiently stirred and storage in these conditions over a period of at least $1-3$ years.

The narratives penned by European explorers in the 15th century
$\mathrm{AD}$, although vague as to the exact lengths of storage time, reinforce the notion that the indigenous Canarian populations stockpiled their harvests in granaries "for many years" (Gómez Escudero, in Morales Padrón, 2008: 436). Ethnographic records on the use of historical collective granaries in the Maghreb, traditionally serving for comparison with the granaries of Gran Canaria (Marcy, 1940; Onrubia Pintado, 1986), advance an imprecise timeframe of 'several years' (Lefébure, 1985; Delaigue et al., 2006, 2011; 2013).

The lack of accuracy of the ethno-historical texts confirms the importance of archaeoentomological analyses for the understanding of former storage techniques. Evidence obtained at La Fortaleza suggests that pests offer accurate information as to long-term storage and serve as indicators of this activity in other archaeological contexts of the Canary Islands and beyond.

\section{Conclusions}

Ensuring human survival in isolated contexts such as the Canary Islands requires a correct managing of a series of different resources. The first settlers of Gran Canaria built granaries high in the cliffs with the aim of storing mostly cereals, pulses and figs all domesticated plants whose origins can be traced to the African continent. The arrival of these plants for future cultivation involuntarily introduced pests that spread throughout a landscape molded by humans. Archaeoentomology is therefore a new and relevant discipline in the Canary Islands as it allows pinpointing the propagation of different pests coexisting with the Prehispanic Canarians and identifying how their presence affected human activities. Nevertheless, the data available are still limited to a few communal granaries, and future studies should extend their analyses settlements and other sites such as burials, where entomological evidence is still missing.

The study of the insects of the granary of La Fortaleza reveals that certain insect pest species, especially those of secondary type, developed during storage periods extending for more than one year. Ethnohistorical written records corroborate long-term storage in collective granaries, a notion bolstered by the fact that the grains were stored with the protection of the ear. Therefore, data obtained at La Fortaleza confirm that insect remains in certain archaeological contexts can be used to estimate the length of food storage. This scenario could be extrapolated to other geographical areas and chronological periods where taphonomical conditions allow the preservation of insect remains.

Finally, an unexpected find of this study is the presence of the spider beetle $M$. americanum in the Old World in a timeframe prior to the European conquest of America (1492). This suggests an African or Eurasian origin rather than one of the New World.

\section{Declaration of competing interest}

$\square$ The authors declare that they have no known competing financial interests or personal relationships that could have appeared to influence the work reported in this paper.

$\square$ The authors declare the following financial interests/personal relationships which may be considered as potential competing interests:

\section{Acknowledgements}

This study benefited from the research project HAR 2017-83205-P funded by the Ministry of Economy and Innovation of Spain, together with FEDER European funds, and the research project 2018 PATRI25 funded by La Caixa and CajaCanarias Foundation. P. Henríquez is beneficiary of a PhD grant from Universidad de Las Palmas de Gran Canaria. J. Morales is beneficiary of a Ramón y Cajal research fellowship funded by the Spanish Ministry of Economy and Innovation of Spain (grant number RYC-2015-18072). P. Vidal-Matutano is funded by the Spanish Government's Ministry of Economy and Innovation, under the "Juan de 
la Cierva-Formación" program (FJCI-2017-32461). The authors are very grateful to Alisios Actividades for support in the field work; and to Timothy Anderson and John Spencer for assistance with an earlier draft of this article.

\section{Appendix A. Supplementary data}

Supplementary data to this article can be found online at https://doi. org/10.1016/j.jas.2020.105179.

\section{References}

Adams, K.R., 1984. Evidence of wood-dwelling termites in archaeological sites in the southwestern United States. J. Ethnobiol. 4 (1), 29-43.

Alberto Barroso, A., Delgado Darias, T., Moreno Benítez, M.A., Velasco Vázquez, F.J., 2019. La dimensión temporal Y el Fenómeno Sepulcral the ancient Canarians. Zephyrus 86 (2), 139-160.

Alfieri, A., 1931. Les insectes de la tombe de Toutankhamon. Bulletin de la Société Royale Entomologique d'Égypte 3/4, 188-189.

Alonso Martínez, N., Juan Tresserras, J., Rodríguez-Ariza, M.O., Rovira Buendía, N., 2000. Muestreo arqueobotánico de yacimientos al aire libre y en medio seco. In: Buxó, R., Piqué, R. (Eds.), La recogida de muestras en arqueobotánica: objetivos y propuestas metodológicas. La gestión de los recursos vegetales y la transformación del paleopaisaje en el Mediterráneo Occidental. Encuentro del grupo de trabajo de arqueobotánica de la Península Ibérica. Barcelona/Bellaterra, pp. 29-46.

Arnay-de-la-Rosa, M., González-Reimers, E., Yanes, Y., Velasco-Vázquez, J., Romanek, C. S., Noakes, J.E., 2010. Paleodietary analysis of the Prehistoric population of the canary islands inferred from stable isotopes (carbon, nitrogen and hydrogen) in bone collagen. J. Archaeol. Sci. 37 (7), 1490-1501.

Balcells, R., Barrera, J.L., Gómez Sainz, J.A., 1990. Mapa geológico de España. Hoja 1114I. Instituto tecnológico geominero de España.

Back, E.A., Cotton, R.T., 1926. Biology of the saw-toothed grain beetle, Oryzaephilus surinamensis Linné. J. Agric. Res. 33 (5), 435-453.

Bain, A., 1998. A Seventeenth-century beetle fauna from colonial Boston. Hist. Archaeol. 32 (3), 38-48.

Bell, C.H., 2014. A review of insect responses to variations encountered in the managed storage environment. J. Stored Prod. Res. 59, 260-274.

Beynon, S.A., Mann, D.J., Slade, E.M., Lewis, O.T., Morgan, E., 2012. Species-rich dung beetle communities buffer ecosystem services in perturbed agro-ecosystems. J. Appl. Ecol. 49 (6), 1365-1372.

Bescherer, K., Beaudry, M.C., 2015. Archaeology of Food: an Encyclopedia. Rowman and Littlefield, Londres.

Borojevic, K., Steiner, W.E., Gerisch, R., Zazzaro, C., Ward, C., 2010. Pests in an ancient Egyptian harbor. J. Archaeol. Sci. 37 (10), 2449-2458.

Borowski, J., 2009. "The spider beetles of the continental Africa (Coleoptera : Ptinidae). Part III. Eutaphroptinus gen. N. From South Africa with description of two new species belonging to the new genus. Studies and Reports of District Museum PragueEast Taxonomical 5 (1-2), 11-16.

Borowski, J., 2017. Mezium americanum (laporte de Castelnau, 1840), a new synonym of Mezium Sulcatum (Fabricius, 1781) (Coleoptera: Ptinidae, gibbiinae, meziini). World Scientific News 65, 171-175.

Buckland, P.C., 1976. The use of insect remains in the interpretation of archaeological environments. In: Davidson, D.A., Shackley, M.L. (Eds.), Geoarchaeology. Earth Science and the Past. Duckworth, London, pp. 369-396.

Buckland, P.C., 1979. Thorne Moors: A Palaeoecological Study of a Bronze Age Site, vol. 8. University of Birmingham, Dept. of Geography, Occasional Papers, Birmingham.

Buckland, P.C., 1981. The early dispersal of insect pests of stored products as indicated by archaeological records. J. Stored Prod. Res. 17- issue 1, 1-12.

Buckland, P.C., 1990. Insects, granaries and stores: the Archaeology of insect Synanthropy. La Préparation Alimentaire des Céréales 26 (September), 69-81.

Chowne, P., Girling, M., Greig, J., 1986. Excavations at an Iron Age defended enclosure at tattershall thorpe, lincolnshire. Proc. Prehist. Soc. 52, 159-188.

Coope, G.R., Osborne, P.J., 1968. Report on the coleopterous fauna of the roman well at barnsley Park, gloucestershire. Trans. - Bristol Glos. Archaeol. Soc. 86, 84-87.

Coope, G.R., 1977. Quaternary Coleoptera as aids in the interpretation of environmental history. In: F W, Shotton (Eds.), British Quaternary Studies: Recent Advances. Oxford University Press, Oxford, pp. 55-68.

Coope, G.R., 1986. Coleoptera analysis. In: B E, Berglund (Eds.), Handbook of HoIocene Palaeoecology and Palaeohydrology. J. Wiley and Sons, New York, pp. 703-713.

Coope, G.R., 1990. The invasion of northern Europe during the Pleistocene by mediterranean species of Coleoptera. In: F, di Castri, A J, Hansen, Debussche, M. (Eds.), Biological Invasions in Europe and the Mediterranean Basin. Kluwer, Dordrecht, pp. 203-215.

Cotton, R.T., 1924. Monograph of the Genus Sitophilus Schoenherr. PhD. Thesis. Faculty of Graduate Studies, George Washington University, Washington D.C.

Crowson, R.A., 1958. Some observations on a coleopterological visit to Central Italy. Entomol. Mon. Mag. 94, 248-251.

Culver, D.C., Pipan, T., 2009. The Biology of Caves and Other Subterranean Habitats. Oxford University Press, New York.

Dal Monte, G., 1956. La presenza di insetti dei granai in frumento trovato negli scavi di Ercolano. Redia 41, 23-28.
Delaigue, M.C., Bokbot, Y., Onrubia Pintado, J., Amarir, A., 2006. Etnoarqueología de los graneros fortificados magrebíes: el agadir de Id Aysa (Amtudi, Marruecos). Treballs d'Etnoarqueologia 6, 161-172.

Delaigue, M.C., Onrubia Pintado, J., Amarir, A., Bokbot, Y., 2011. Une technique d'engrangement, un symbole perché. Le grenier fortifié Nord-afrocain. Tech. Cult. $57,2-21$.

Delaigue, M.C., Onrubia Pintado, J., Bokbot, Y., 2013. "El agadir de Id Aysa (Amtudi, Marruecos). Materialidad y espacio social. In: De la estructura doméstica al espacio social. Lecturas arqueológicas del uso social del espacio. Publicaciones Universidad de Alicante, pp. 299-313.

Delgado-Darias, T., 2009. La historia de los dientes. Una aproximación a la Prehistoria de Gran Canaria desde la Antropología Dental. In: Cabildo de Gran Canaria. Las Palmas de Gran Canaria.

Delobel, A., Tran, M., 1993. Les Coléoptères Des Denrées Alimentaires Entreposées Dans Les Régions Chaudes. Orstom, Paris.

Denux, O., Zagatti, P., 2010. Coleoptera families other than Cerambycidae, Curculionidae sensu lato, Chrysomelidae sensu lato and Coccinelidae, Chap 8.5. In: Roques, A., Kenis, M., Lees, D., Lopez-Vaamonde, D.L., Rabitch, W., Rasplus, J.-Y., Roy, D.B. (Eds.), BioRisk vol. 4, 315-406. Alien Terrestrial Arthropods of Europe.

Fregel, R., Ordóñez, A., Santana-Cabrera, J., Cabrera, V., Velasco-Vázquez, J., Alberto, V., Moreno-Benítez, M.A., Delgado-Darias, T., Rodríguez-Rodríguez, A., Hernández, J., Pais, J., González-Montelongo, R., Lorenzo-Salazar, J.M., Flores, C., Cruz-de-Mercadal, M.C., Álvarez-Rodríguez, N., Shapiro, B., Arnay, M., Bustamante, C.D., 2019. Mitogenomes illuminate the origin and migration patterns of the indigenous People of the canary islands. Plos One 14 (3), 1-24.

Forbes, V., Milek, K., 2014. 'Insects, activity areas and turf buildings' interiors: an ethnoarchaeoentomological case study from 19th to early 20th-century verá, northeast Iceland. Quat. Int. 341, 195-215.

Giordani, G., Erauw, C., Eeckhout, P.A., Owens, L.S., Vanin, S., 2020. "Patterns of camelid Sacrifice at the site of Pachacamac, Peruvian central coast, during the late intermediate period (AD1000-1470): Perspectives from funerary archaeoentomology. J. Archaeol. Sci. 105065.

Hagenblad, J., Morales, J., Leino, M.W., Rodríguez-Rodríguez, A., 2017. Farmer Fidelity in the canary islands revealed by ancient DNA from Prehistoric seeds. J. Archaeol. Sci. 78, 78-87.

Hagstrum, D.W., Subramanyam, B., 2009. Stored-Product Insect Resource. AACC International. Minnesota, USA.

Haines, C.P., 1991. Insects and Arachnids of Tropical Stored Products: Their Biology and Identification, second ed. Natural Resources Institute, Chatham, Kent.

Halstead, D.G.H., 1993. Keys for the identification of beetles associated with stored products-II. Laemophloeidae, Passandridae and Silvanidae. J. Stored Prod. Res. 29 (2), 99-197.

Henríquez-Valido, P., Morales, J., Vidal-Matutano, P., Santana-Cabrera, J., Rodríguez Rodríguez, A., 2019. Arqueoentomología Y arqueobotánica de Los espacios de Almacenamiento a largo Plazo: el granero de Risco Pintado, temisas (gran Canaria). Trab. Prehist. 76 (1), 11-28.

Huchet, J.-B., 2017. Le Coléoptère, la Graine et l'Archéologue: approche archéoentomologique des principaux ravageurs des denrées stockées. In: Diestch Sellami, M.-F., et al. (Eds.), Plantes, produits végétaux et ravageurs. Aquitania, pp. 17-42 (supl. 36).

Kenward, H., Carrott, J., 2006. Insect species associations characterise pest occupation sites. J. Archaeol. Sci. 33, 1452-1473.

Kingsolver, J., 1991. Dermestid beetles (dermestidae, Coleoptera). In: Insect and Mite Pests in Food. An Illustrated Key, vol. 1, pp. 115-135.

Kislev, M.E., Simchoni, O., 2007. Hygiene and insect damage of crops and foods at Masada. In: Aviram, et al. (Eds.), The Masada Reports, pp. 133-170.

Lefébure, C., 1985. Réserves céréalières et société: ĺensilage chez les marocains. In: En, M., Gast, y, Sigaut, F. (Eds.), Les techniques de conservation des grains á long terme, vol. 3. C.N.R.S. Paris, pp. 211-236 fasc. 1.

Lepesme, P., 1944. Les Coléoptères des denrées alimentaires et des produits industriels entreposés, vol. XXII. Encyclopédie entomologique., Paris.

Levinson, H.Z., Levinson, A.R., 1985. Storage and insect species of stored grain and tombs in ancient Egypt. Zeitschrift fiirange- wandte Entomologie 100, 321-339.

Levinson, H., Levinson, A., 1994. Origin of grain storage and insect species consuming desiccated food. Anzieger Schadlingskunde, Pfanzenschutz, Umweltschultz 67, 47-59.

Maca-Meyer, N., Arnay, M., Rando, J.C., Flores, C., González, A.M., Cabrera, V., Larruga, J.M., 2004. Ancient mtDNA analysis and the origin of the Guanches. Eur. J. Hum. Genet. 12 (2), 155-162.

Machado, A., Oromí, P., 2000. Elenco de los coleópteros de las islas Canarias. Catalogue of the coleoptera of the Canary Islands. Instituto de Estudios Canarios, Santa Cruz de Tenerife.

Marcy, G., 1940. La vrai destination des Pintaderas des Iles Canaries. Journal de la Société des Africanistes (París), X. 163-180.

Matterne, V., Yvinec, J.H., Gemehl, D., 1998. Stockage de plantes alimentaires et infestation par les insectes dans un grenier incendié de la fin du IIe siècle après J.-C. à Amiens (Somme). Rev. Archeol. Picardie 3-4, 93-122.

McCauley, R., Bostock, E., Elrington, P., Natale, G., Lenzi, P., Vanin, S., 2014. Insects from pre-Colombian Peruvian mummies: a funerary archaeoentomological approach. In: 11th Meeting of the European Association for Forensic Entomology, Lille, pp. 70-72.

Morales, J., 2010. El Uso de Las Plantas En La Prehistoria de Gran Canaria: Alimentación, Agricultura Y Ecología. Gran Canaria: Cabildo Insular de Gran Canaria.

Morales, J., Rodríguez-Rodríguez, A., González-Marrero, M.C., Martín-Rodríguez, E., Henríquez-Valido, P., Del-Pino-Curbelo, M., 2014. "The archaeobotany of long-term. crop storage in northwest african communal granaries: a case study from 
PreHispanic gran Canaria (cal. Ad 1000-1500). Veg. Hist. Archaeobotany 23 (6), 789-804.

Morales, J., Henríquez-Valido, P., Moreno-Benítez, M., Naranjo-Mayor, Y., RodríguezRodríguez, A., 2018. "Du laurier dans les greniers de Grande Canarie: insecticide naturel et conservation longue des récoltes à l'époque préhispanique (ca. 500-1500 AD). Tech. Cult. 69, 1-21.

Morales Padrón, F., 2008. Canarias: crónicas de Su conquista. In: Cabildo de Gran Canaria. 3rded. Las Palmas de Gran Canaria.

Moreno, M.A., 2017. La Fortaleza, historia de una idea. In: Carretero, Andrés (Ed.), Boletín del Museo Arqueológico Nacional, 35. Ministerio de Educación, Cultura y Deporte, Madrid, Spain, pp. 750-755.

Moreno, M.A., Mendoza, F., Suárez, I., Alberto, V., Martínez, M.A., 2017. Un día cualquiera en La Fortaleza. Resultados de las intervenciones arqueológicas 2015 2016, vols. XXII-136. Santa Lucía de Tirajana, Gran Canaria, pp. 1-9.

Naranjo-Mayor, Y., Rodríguez-Rodríguez, A., 2015. Artefactos e instrumentos de piedra en un espacio de almacenamiento colectivo. El caso de El Cenobio de Valerón (Gran Canaria, España). Munibe Antropologia-Arkeologia 66, 291-308.

Onrubia Pintado, J., 1986. Sellos y marcas de propiedad de graneros fortificados del Aurés (Argelia). Consideraciones etnoarqueológicas en torno a las presuntas correlaciones norteafricanas de las pintaderas de Gran Canaria. Trab. Prehist. 43, 281-307.

Onrubia Pintado, J., 2003. La Isla de Los Guanartemes: territorio, sociedad y poder en la Gran Canaria indígena (siglos XIV-XV). Cabildo Insular de Gran Canaria. Las Palmas de Gran Canaria.

Osborne, J., 1969. An insect fauna of late Bronze Age date from wilsford, wiltshire. J. Anim. Ecol. 38, 555-566.

Panagiotakopulu, E., Buckland, P.C., 1991. Insect pests of stored products from late Bronze Age Santorini, Greece. Journal of stored Product Research 27, 179-184.

Panagiotakopulu, E., Van Der Veen, M., 1997. Synanthropic insect faunas from Mons Claudianus, a roman quarry site in the eastern desert. Quat. Proc. 5, 199-206.

Panagiotakopulu, E., 2001. New records for ancient pests: archaeoentomology in Egypt. J. Archaeol. Sci. 28, 1235-1246.

Panagiotakopulu, E., Buckland, P.C., Kemp, B., 2010. "Underneath ranefer's Floors urban environments on the desert edge". J. Archaeol. Sci. 37, 474-481.

Panagiotakopulu, E., Higham, T., Sarpaki, A., Buckland, P.C., Doumas, C., 2013. Ancient pests: the Season of the Santorini minoan volcanic eruption and a date from insect chitin. Naturwissenschaften 100 (7), 683-689.

Panagiotakopulu, E., Higham, T., Buckland, P.C., Tripp, J.A., Hedges, R.E.M., 2015. AMS dating of insect chitin - a discussion of new dates, problems and potential. Quat. Geochronol. 27 (February), 22-32.

Panagiotakopulu, E., Buckland, P.C., 2018. Early invaders: Farmers, the granary weevil and other uninvited guests in the neolithic. Biol. Invasions 20, 219-233.

Ponel, P., Matterne, V., Coulthard, N., Yvinec, J.H., 2000. La tène and gallo-roman natural environments and human impact at the Touffréville rural settlement, reconstructed from Coleoptera and plant macroremains (calvados, France) J. Archaeol. Sci. 27, 1055-1072.

Plarre, R., 2010. An attempt to reconstruct the natural and cultural history of the granary weevil, Sitophilus granarius (Coleoptera: Curculionidae). Eur. J. Entomol. 107 (1), $1-11$.

Rodilla, J.M., Tinoco, M.T., Morais, J.C., Gimenez, C., Cabrera, R., Martín-Benito, D., Castillo, L., González-Coloma, A., 2008. «Laurus novocanariensis essential oil: Seasonal variation and valorization». Biochem. Systemat. Ecol. 36, 167-176.
Rodríguez Rodríguez, A., Morales, J., del Pino Curbelo, M., Naranjo Mayor, Y., Martín Rodríguez, E., González Marrero, M.C., 2011-2012. Espacios de producción especializada, excedentes y estratificación social en la Gran Canaria pre-europea. Tabona: Revista de Prehistoria y de Arqueología 19, 101-123.

Rodríguez-Varela, R., Günther, T., Krzewinska, M., Storå, J., Gillingwater, T.H., MacCallum, M., Girdland-Flink, L., 2017. Genomic analyses of pre-european conquest human remains from the Canary Islands reveal close affinity to modern North. Curr. Biol. 27, 3396-3402.

Sahito, H.A., Ahmed Mallah, N., Kousar, T., Ali, W., Shah, Z.H., Jatoi, F.A., Muhammad, W., 2017. Life table Parameters of saw toothed grain beetle Oryzaephilus surinamensis (L., 1758) on different varieties of stored date palm fruits infested under laboratory conditions. Journal of Entomology and Zoology Studies 5 (1), 95-99.

Schmidt, E., 1998. Der Kornkäfer Sitophilus granarius Schön. (Curculionidae) aus der Schuttschicht des bankeramischen Brunnens von Erelenz-Kückhoven. Ö st Rhein. Amtfür Bodendenkmalpflege (Hg.) (Brunnen der Jungteinzeit.Internat. Symposium Erkelenz 27-20 Okt. 1997). Mater Bodendenkmalpfl 11, 261-269.

Schmidt, E., 2013. Vorratsschädlinge im Mitteleuropa des 5. Jahrtausends. In: Gleser, H. G., Becker, V. (Eds.), Beiträge zur Internationalen Konferenz in Münster 2010. Mitteleuropa im 5. Jahrtausend vor Christus Bd. 18. Münster, Berlin, pp. 319-329.

Sigaut, F., 1988. A method for identifying grain storage techniques and its application for European Agricultural History. Tools \& Tillage 6, 3-32.

Solomon, N.E., 1965. Archaeological records of storage pests: Sitophilus granarius (L.) (Coleoptera, Curculionidae) from an Egyptian pyramid tomb. Journal of Stored Product Research 1, 105-107.

Springer, R., 2001. Origen y uso de la escritura líbico-bereber en Canarias. Centro de la Cultura Popular, Sta. Cruz de Tenerife.

Trematerra, P., Sciarreta, A., Tamasi, E., 2000. Behavioural responses of Oryzaephilus surinamensis, Tribolium castaneum and Tribolium confusum to naturally and artificially damaged durum wheat kernels. Entomol. Exp. Appl. 94 (2), 195-200.

Valamoti, S., Buckland, P.C., 1995. An early find of Oryzaephilus surinamensis (L.) (Coleoptera: Silvanidae) from final Neolithic Mandalo, Macedonia, Greece. J. Stored Prod. Res. 31 (4), 307-309.

Velasco Vázquez, J., 1998. Economía y dieta de las poblaciones prehistóricas de Gran Canaria: una aproximación bioantropológica. Complutum 9, 137-160.

Velasco-Vázquez, J., Alberto Barroso, V., Delgado Darias, T., Moreno, M.A., Lécuyer, C., Richardin, P., 2020. Poblamiento, colonización y primera historia de Canarias: el C14 como paradigma. Anu. Estud. Atl. 66, 1-24.

Vidal-Matutano, P., Morales, J., Henríquez-Valido, P., Marchante Ortega, A., Moreno Benítez, M.A., Rodríguez Rodríguez, A., 2020. El uso de la madera en espacios de almacenamiento colectivos: análisis antracológico (carbones y maderas) de los silos de La Fortaleza (Santa Lucía de Tirajana, Gran Canaria), 20. Anuario de la Facultad de Geografía e Historia, Vegueta, pp. 469-489.

Zacher, F., 1937. Vorratschadlinge und Vorratschutz, ihre Bedeutung für Volksernaührung und Weltwirtschaft. Zeitschrift für hygienische Zoologie und Schaüdlingsekampfung 29, 193-202.

Zohary, D., 1969. The progenitors of wheat and barley in relation to domestication and agriculture dispersal in the Old World. The domestication and exploitation of plants and animals 47-66. 